\title{
RESIDUAL STRESS STATE IN SINGLE-EDGE NOTCHED TENSION SPECIMEN CAUSED BY THE LOCAL COMPRESSION TECHNIQUE
}

\begin{abstract}
Three-dimensional (3D) finite element analyses (FEA) are performed to simulate the local compression (LC) technique on the clamped single-edge notched tension $(\mathrm{SE}(\mathrm{T}))$ specimens. The analysis includes three types of indenters, which are single pair of cylinder indenters (SPCI), double pairs of cylinder indenters (DPCI) and single pair of ring indenters (SPRI). The distribution of the residual stress in the crack opening direction in the uncracked ligament of the specimen is evaluated. The outcome of this study can facilitate the use of LC technique on SE(T) specimens.
\end{abstract}

\section{Introduction}

The fracture toughness resistance curve, i.e. the $J$-integral resistance $(J-R)$ or crack tip opening displacement resistance $(C T O D-R)$ curve is an important input in the engineering critical assessment (ECA) of steel structures such as pressure vessels and energy pipelines. The resistance curve is typically obtained from deeply-cracked single-edge bend ( $\mathrm{SE}(\mathrm{B})$ ) or compact tension $(\mathrm{C}(\mathrm{T})$ ) specimens as standardized in ASTM E1820-13 [1] and BS7448-4 [2]. Recently, the use of the non-standard single-edge (notched) tension (SE(T) or SENT) specimen to determine the resistance curve has gained significant research interests (e.g. [3, 4]) in the energy pipeline industry largely as a result of the development of the strain-based design and assessment methodologies. Fig. 1 schematically shows the configuration of a typical SE(T) specimen including the width $(W)$, thickness $(B)$, crack length $(a)$ and the daylight distance (distance between the clamped surfaces, $H$ ) of the specimen.

\footnotetext{
${ }^{1}$ Department of Civil \& Environmental Engineering, Carleton University, Ottawa, Ontario, Canada,Email: yifan.huang@carleton.ca

${ }^{2}$ Department of Civil \& Environmental Engineering, University of Western Ontario, London, Ontario,Canada,Email: wzhou@eng.uwo.ca
} 


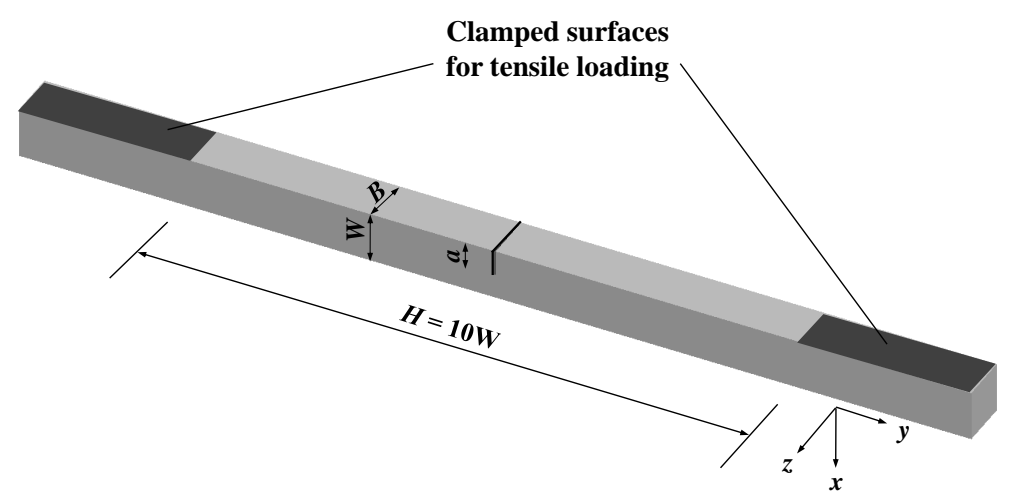

Fig. 1. Schematic of SE(T) specimen

Many engineering manufacturing and structural construction processes inevitably introduce residual stresses in the engineering components. One example is the residual stress caused by the thermal cycles during the welding procedures [5]. It is well-known that the residual stress has a non-negligible impact on the fracture toughness of the material/structural component [5]. The fracture toughness corresponding to the opening mode (mode I) is largely impacted by the opening residual stress, $\sigma_{y y(R)}$. In general, the tensile opening residual stress promotes the crack growth whereas the compressive opening residual stress retards the crack growth [5]. As a result, a non-uniform distribution of residual stress along the crack front yields a non-uniform crack growth, i.e., a curved crack front. To ensure the accuracy of the experimentally determined $J(C T O D)-R$ curve, testing standards (e.g. $[1,2])$ usually specify acceptable levels of the crack front curvature for both the fatigue pre-crack and final crack fronts for the $\mathrm{SE}(\mathrm{B})$ and $\mathrm{C}(\mathrm{T})$ specimens.

For specimens containing notches or cracks located at weldments or the heataffected zone, the residual stress in the uncracked ligament can be high and nonuniformly distributed along the crack front. In such cases, treatments are required to mitigate the residual stress prior to the fatigue pre-cracking. The local compression (LC) technique [6-8] is one of the mechanical treatment techniques that produce additional residual stresses to mitigate the existing residual stresses. Many experimental and numerical studies [6, 7, 9-14] have been carried out to investigate the applicability of the $\mathrm{LC}$ technique for $\mathrm{SE}(\mathrm{B})$ and $\mathrm{C}(\mathrm{T})$ specimens. The focus of these studies is $\mathrm{SE}(\mathrm{B})$ and $\mathrm{C}(\mathrm{T})$ specimens with $a / W \geqslant 0.3$ and $0.25 \leqslant B / W \leqslant 1$. To our best knowledge, the applicability of the LC technique for SE(T) specimens has not been numerically investigated. Motivated by this observation, we carry out three-dimensional (3D) finite element analyses (FEA) to investigate the opening residual stress state in the $\mathrm{SE}(\mathrm{T})$ specimen $(a / W=0.25, B / W=1)$ caused by different LC techniques in the present study.

The rest of the paper is structured as follows. Section 2 presents a review of three different LC techniques in the literature. Section 3 describes the configura- 
tions of the FE models, material properties and computational procedures. The opening residual stress states corresponding to the three reviewed LC techniques are analyzed and compared in Section 4, followed by conclusions in Section 5.

\section{The local compression technique}

\subsection{Single Pair of Cylinder Indenters (SPCI)}

Fig. 2a illustrates the schematics of the typical LC method. As shown in the figure, a single pair of cylinder indenters (SPCI) are used to apply the out-ofplane (i.e., $z$ direction) compression on the notched specimen. The indenter has a radius of $R$. The origin of the $x-y-z$ coordinate system is the notch tip at the mid-thickness of the specimen. $\delta_{x}$ and $\delta_{y}$ denote the distances between the centre of the indenter and notch tip in the $x$ and $y$ directions, respectively. For SPCI, $\delta_{y}=0$. As specified in Annex C of ISO15653 [8], a standard for the fracture toughness testing of welds, $88 \%$ to $92 \%$ of the ligament in front of the machined notch shall be compressed (i.e., $\left.\delta_{x}=(88 \% \sim 92 \%)(W-a)-R\right)$. The indentation is controlled by the plastic deformation, which shall not exceed $0.5 \% B$ on each side. Early experimental studies $[6,7]$ on through-wall cracked specimens revealed that using the LC technique with SPCI can effectively mitigate the residual stress in the specimens with weld materials and leads to relatively straight crack front. Many numerical studies (e.g. [9-12]) have been carried out to investigate the applicability of the SPCI technique for SE(B) and C(T) specimens.

\subsection{Double Pairs of Cylinder Indenters (DPCI)}

Mahmoudi et al. [11, 12] developed an LC technique by using double pairs of cylinder indenters (DPCI) (see Fig. 2b). It is reported in [11] that DPCI can produce either tensile or compressive opening residual stress depending on $\delta_{x}$ and $\delta_{y}$. It was found that the initial plastic strain adjacent to the crack tip leads to lower failure ductility [11]. Compared with SPCI, DPCI leads to smaller plastic strains near the crack tip at similar levels of the opening residual stress, and therefore reduces the impact of the plastic strain on toughness.
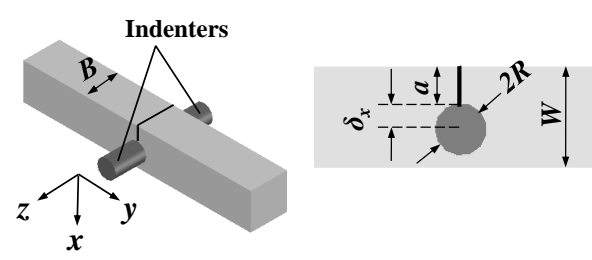

(a) Single pair of cylinder indenters (SPCI)

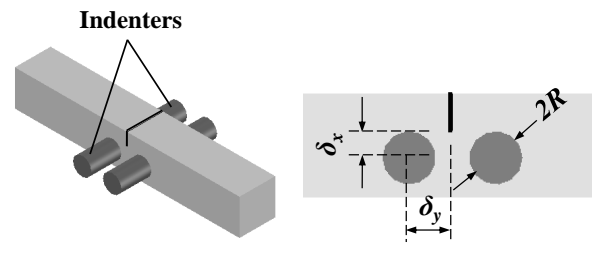

(b) Double pairs of cylinder indenters (DPCI)

Fig. 2. The local compression technique 


\subsection{Single Pair of Ring Indenters (SPRI)}

Lim et al. [14] suggested using a single pair of ring indenters (SPRI) to produce compressive residual stress near the crack tip. Based on the experiments results for the thin plate $(B / W=0.04) \mathrm{SE}(B)$ specimens reported in [14], SPRI can effectively retard the fatigue crack growth. However, the residual stress state caused by SPRI has not been numerically investigated in the literature, and will be addressed in the present paper.

\section{Numerical analyses}

\subsection{Finite Element Model}

The FEA code ABAQUS® [15], was employed to simulate the LC technique. Three-dimensional models of SE(T) specimens with $W=20 \mathrm{~mm}, H / W=10$, $a / W=0.25$ and $B / W=1$ were prepared for FEA. Three types of indenters, i.e., SPCI, DPCI and SPRI, were considered in the analysis. The configurations of the cylinder and ring indenters are shown in Figs. $3 \mathrm{a}$ and $3 \mathrm{~b}$, respectively, with the radius of the indenters $R=5 \mathrm{~mm}$. For SPCI, three indenter positions (i.e., $\delta_{x}=0$, $0.5 R$ and $1.0 R$ ) are considered, whereas only one indenter position is considered for DPCI (i.e., $\delta_{x}=0$ and $\delta_{y}=1.2 R$ ) and SPRI (i.e., $\delta_{x}=0$ ).

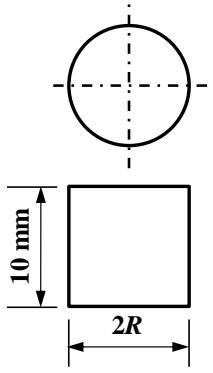

(a) Cylinder indenter

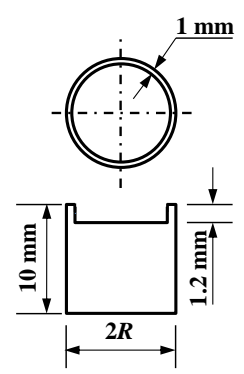

(b) Ring indenter

Fig. 3. Configurations of the indenters

Because of symmetry, only one quarter of the specimen with appropriate constraints imposed on the remaining ligament was modelled. A typical quartersymmetric 3D model has 15 layers equally-distributed over the half thickness $(B / 2)$. The total number of elements is approximately 30,400 in a typical specimen. The specimen model was constructed primarily by using the 8 -node 3D brick elements with reduced integration (i.e. C3D8R), while the 6-node 3D triangular prism elements (i.e. C3D6) were used to provide the transition from the coarse to fine meshes. The material properties of these elements are described in Section 3.2. A typical FE model is shown in Fig. 4. An electrical discharge machining (EDM) notch tip with a radius $(r=0.1 \mathrm{~mm})$ as suggested in E1820 [1] was 
incorporated in the FE model (see Fig. 4). All of the FE models have 50 focused annular rings around the notch tip with 20 elements in each ring. The minimum in-plane dimension of the first ring is about $0.2 r$. The indenter was modelled using the 3-node 3D rigid triangular facet elements (i.e. R3D3). A frictionless contact between specimen and indenter was assumed.

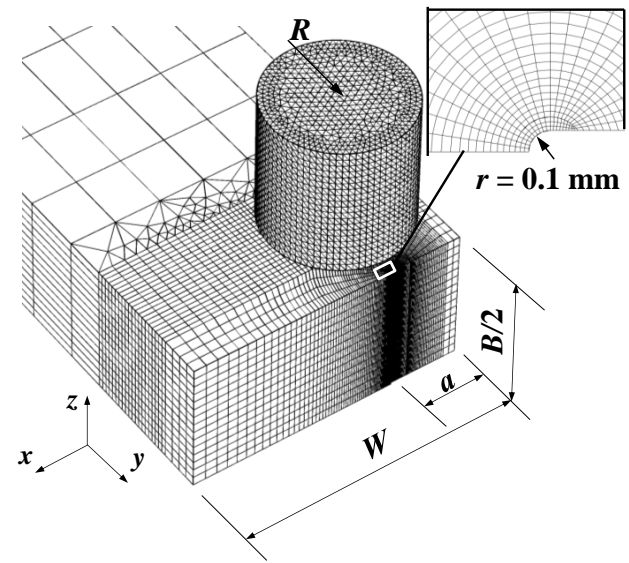

Fig. 4. Typical FE model with DPCI

\subsection{Material properties}

The finite-strain (nonlinear geometry change) formulation was employed in FEA as it can more accurately simulate the deformed configuration of the specimen than the small-strain formulation. The analyses utilized an elastic-plastic constitutive model based on the incremental theory of plasticity [16]. The von Mises yield criterion and isotropic hardening rule were adopted in the analysis. The von Mises yield criterion states that yielding starts once the second invariant of the deviatoric stress tensor, $J_{2}$, reaches a critical value of $\sigma_{Y S}^{2} / 3$, with $\sigma_{Y S}$ being the material yield strength determined from uniaxial tension test [16]. The true stress $(\sigma)$ and true strain $(\varepsilon)$ relationship of the material is characterized as follows:

$$
\frac{\varepsilon}{\varepsilon_{0}}= \begin{cases}\frac{\sigma}{\sigma_{Y S}}, & \varepsilon \leqslant \varepsilon_{0} \\ \left(\frac{\sigma}{\sigma_{Y S}}\right)^{n}, & \varepsilon>\varepsilon_{0}\end{cases}
$$

where $\varepsilon_{0}\left(\varepsilon_{0}=\sigma_{Y S} / E\right)$ is the yield strain; $E$ is the elastic (Young's) modulus, and $n$ denotes the strain hardening exponent. The incremental theory of plasticity combined with the associate flow rule and von Mises yield criterion can be characterized by the following constitutive equation [16]:

$$
\mathrm{d} \varepsilon_{i j}^{p l}=\mathrm{d} \lambda s_{i j}
$$


where $\varepsilon_{i j}^{p l}$ and $s_{i j}$ are the plastic strain tensor and the deviatoric stress tensor, respectively, and $\mathrm{d} \lambda$ is a scalar factor of proportionality that can be evaluated using the consistency condition [16]. The yield strength, elastic modulus and Poisson's ratio and strain hardening exponent were assumed to be $510 \mathrm{MPa}, 207 \mathrm{GPa}, 0.3$ and 13 , respectively.

\subsection{Computational procedure}

The static load was applied based on the displacement control condition. Displacements were applied on a reference point associated with the rigid indenter. The applied displacement firstly increased to the target indentation values $(h)$ and then decreased to zero (i.e., unloading). The opening residual stress, $\sigma_{y y(R)}$, in the uncracked ligament was then output from FEA. In this study, five loading cases (i.e., $h=0.25 \%, 0.5 \%, 0.75 \%, 1 \%$ and $1.5 \% \mathrm{~B}$ corresponding to total indentation of $0.5 \%, 1 \%, 1.5 \%, 2 \%$ and $3 \% B$ ) were considered.

\section{Results and discussions}

Figs. 5a, 5b and 5c show the surface distribution of $\sigma_{y y(R)}$ (normalized by $\left.\sigma_{Y S}\right)$ on the specimen uncracked ligaments for three representative cases, i.e., LC techniques with SPCI, DPCI and SPRI, respectively, with the indentation level $h=0.5 \% B$. Note that $x=0$ denotes the crack front, and $z=0$ and $B / 2$ denote the
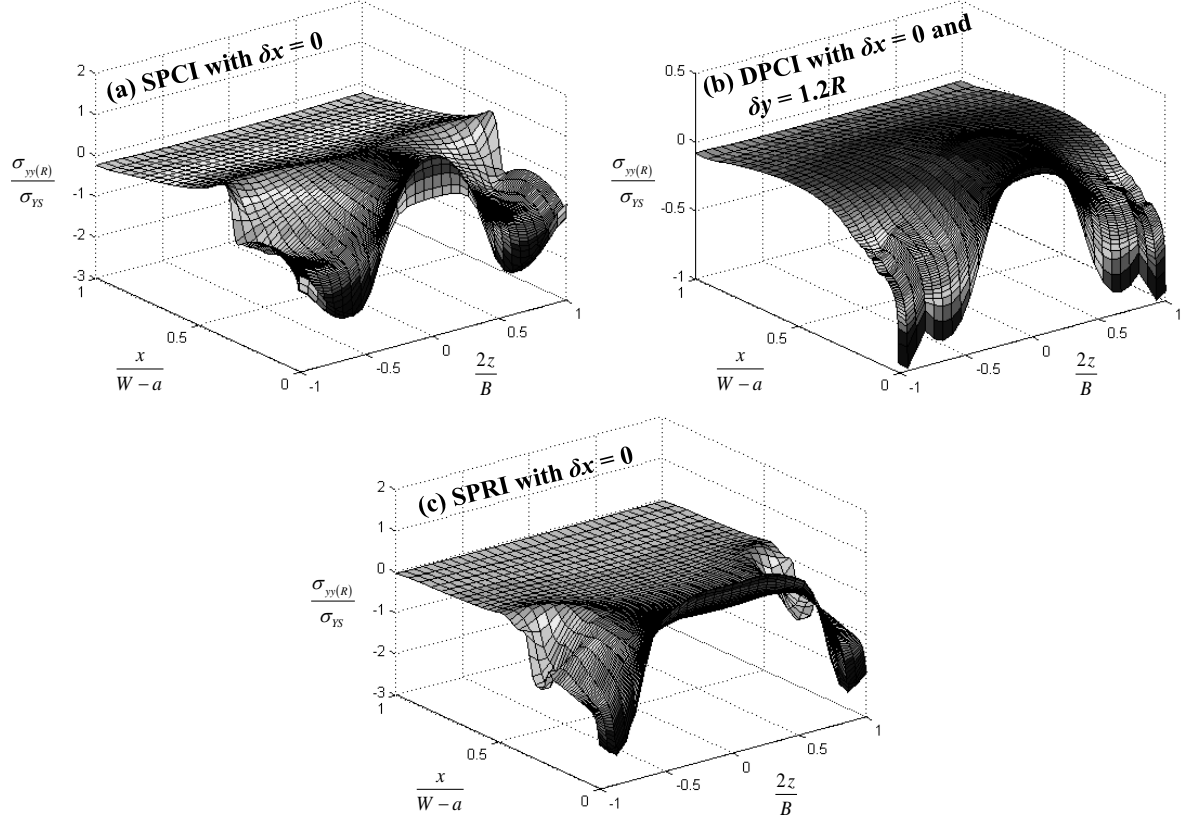

Fig. 5. Surface distribution of $\sigma_{y y(R)} / \sigma_{Y S}$ in the uncracked ligament for $h=0.5 \% B$ 
mid-plane and free surfaces of the specimen, respectively. Positive and negative values of $\sigma_{y y(R)} / \sigma_{Y S}$ represent tensile and compressive stresses, respectively. According to these figures, the stress distribution profile highly depends on the configuration of the indenter. Since $\sigma_{y y(R)}$ needs to be self-balanced on the ligament surface, there always exists both tensile stress and compressive stress regardless of the indenter configuration. High stress gradients are observed at the region $x /(W-a) \leqslant 0.4$. The residual stress state is very complicated at this region and $\sigma_{y y(R)}$ changes significantly along $x$ and $z$ axis.

On the other hand, $\sigma_{y y(R)}$ shows relative less dependence on the coordinates for $x /(W-a)>0.4$. In order to further investigate the impacts of the indenter configuration, positions and indentation levels on the opening residual stress state, two line distributions of $\sigma_{y y(R)}$, i.e., along $x$ and $z$ directions for a fixed $z$ and $x$ values, respectively, were output and are shown in Figs. 6 and 7.

Figs. 6a-6e show the distribution of $\sigma_{y y(R)}$ at the mid-plane (i.e., $z=0$ ) ahead of the crack tip for all the cases analyzed. A previous study [12] suggests that the distribution of $\sigma_{y y(R)}$ along $x$ direction is the same for specimens with sharp and blunt crack (notch) tips when $x \geqslant r$. Therefore, only $\sigma_{y y(R)}$ for $x \geqslant r$ (or $x \geqslant 0.007(W-a)$ ) are shown in these figures to eliminate the dependence of $\sigma_{y y(R)}$ on $r$. Figs. 6a-6c indicate that as $x$ increases from 0.007 to $0.02(W-a)$, the value of $\sigma_{y y(R)} / \sigma_{Y S}$ associated with SPCI rapidly increases from $0-0.8$ to $1.3-1.8$ followed by a rapid decrease. For $h \leqslant 0.5 \% B, \sigma_{y y(R)} / \sigma_{Y S}$ decreases to around zero as $x$ further increases. For $h>0.5 \% B$, there is a second increase of $\sigma_{y y(R)} / \sigma_{Y S}$ at $0.2(W-a) \leqslant x \leqslant 0.8(W-a)$ before the second decrease to $0-$ $(-1)$. Fig. 6e suggests that $\sigma_{y y(R)} / \sigma_{Y S}$ associated with SPRI consistently decreases from $0.5-1.5$ to $0-(-0.2)$ as $x$ increases from 0.007 to $1.0(W-a)$. On the other hand, the value of $\sigma_{y y(R)} / \sigma_{Y S}$ associated with DPCI (see Fig. 6d) slowly increases from -0.5 to 0.5 as $x$ increases from 0 to $0.5(W-a)$, and decreases back to -0.5 as $x$ further increases.

Figs. 7a-7e show the distribution of $\sigma_{y y(R)}$ near the crack tip (i.e., $x=$ $0.007(W-a)$ ) along the crack front. It is observed from Fig. 7a, $7 \mathrm{~b}$ and $7 \mathrm{e}$ that the indentations caused by SPCI with $\delta_{x}=0$ and $0.5 R$ and SPRI with $\delta_{x}=0$ produce compressive stress near the specimen free surfaces (i.e., approximately $|2 z / B| \geqslant 0.5)$ and relatively uniform tensile stress at $|2 z / B|<0.5$. On the other hand, SPCI with $\delta_{x}=R$ (see Fig. 7c) and DPCI (see Fig. 7d) yields consistent tensile and compressive $\sigma_{y y(R)}$ along the crack front, respectively. Figs. 7a, $7 \mathrm{~b}$ and $7 \mathrm{~d}$ suggest that when increasing the indentation from $0.25 \% B$ to $1.5 \% B$, the curves associated with $h=0.25 \% B$ basically moves down by about $1.0 \sigma_{y y(R)} / \sigma_{Y S}$.

Both Figs. 6 and 7 suggest that the distribution of $\sigma_{y y(R)}$ in the uncracked ligament is dependent on the configuration and position of the indenters, which agrees with the findings in the literature $[11,12]$ with respect to LC technique on $\mathrm{C}(\mathrm{T})$ specimens. Once the existing residual stress state in the specimen is given, using the LC method with choices of appropriate indenters and indentation can effectively mitigate the existing residual stress in $\mathrm{SE}(\mathrm{T})$ specimen. 


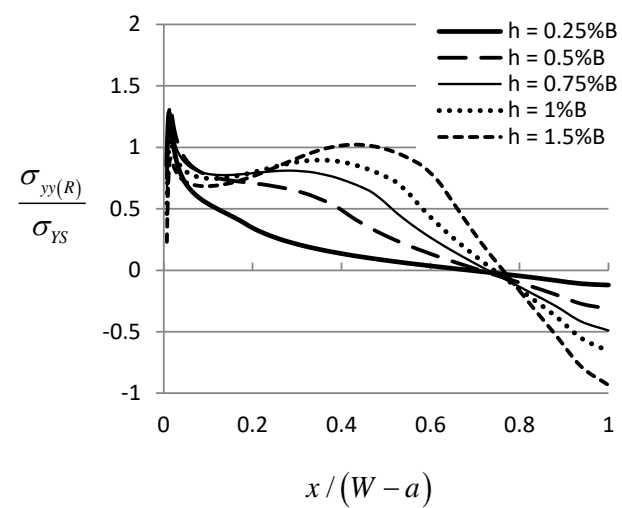

(a) SPCI with $\delta x=0$

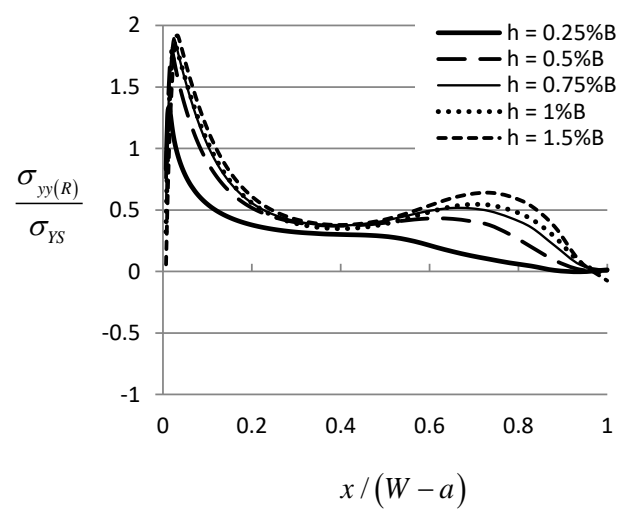

(c) SPCI with $\delta x=R$

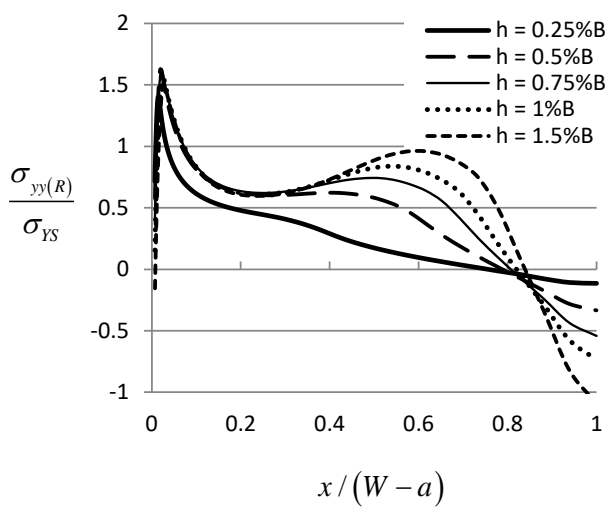

(b) SPCI with $\delta x=0.5 R$

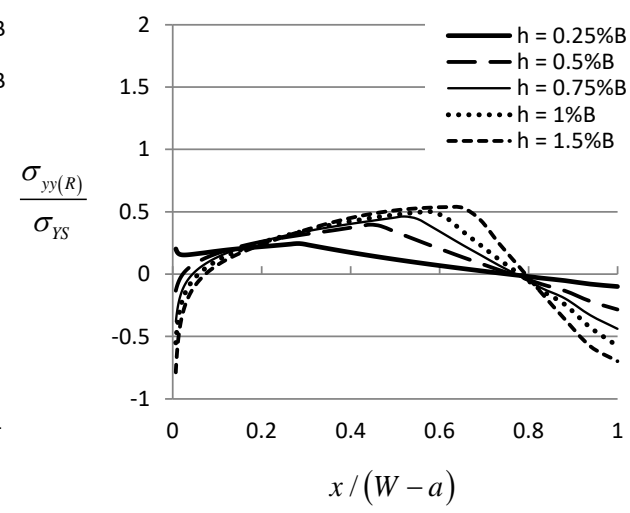

(d) DPCI with $\delta x=0$ and $\delta y=1.2 R$

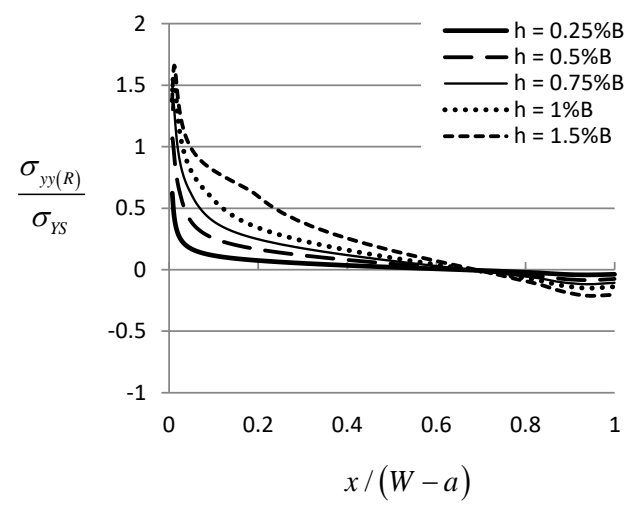

(e) SPRI with $\delta x=0$

Fig. 6. Distribution of $\sigma_{y y(R)} / \sigma_{Y S}$ ahead of crack tip at specimen mid-thickness $(z=0)$ 


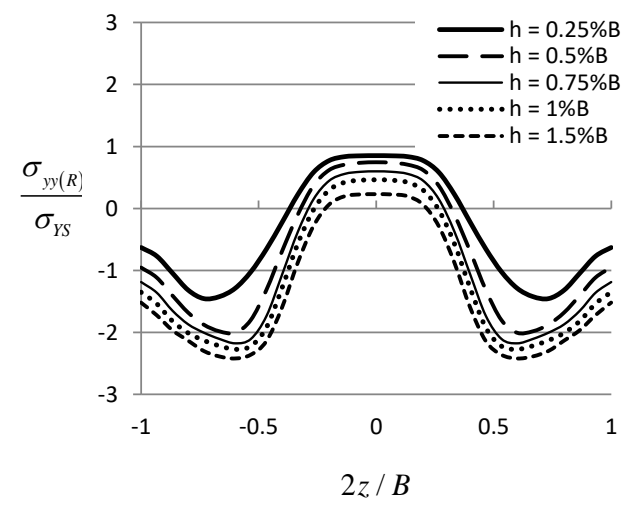

(a) SPCI with $\delta x=0$

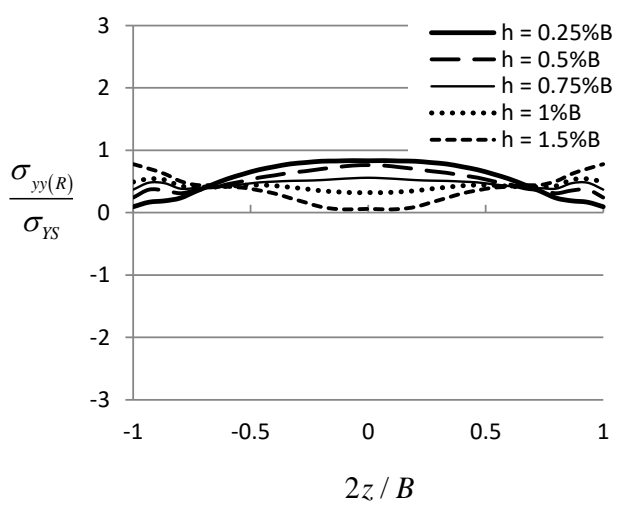

(c) SPCI with $\delta x=R$

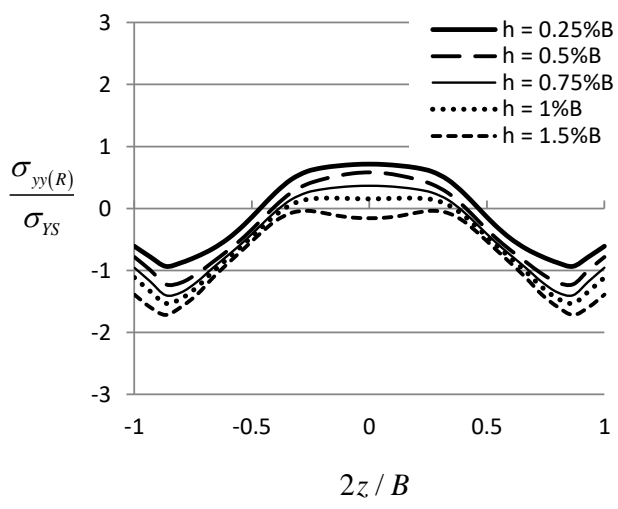

(b) SPCI with $\delta x=0.5 R$

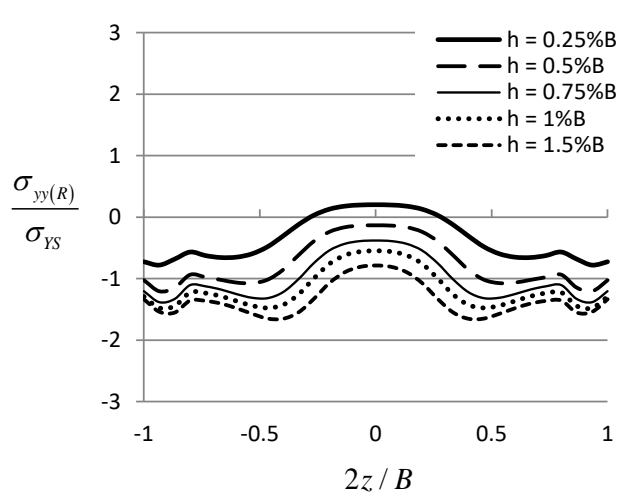

(d) DPCI with $\delta x=0$ and $\delta y=1.2 R$

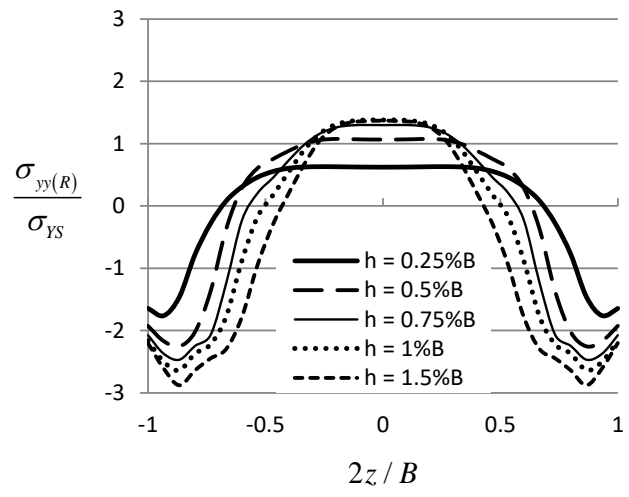

(e) SPRI with $\delta x=0$

Fig. 7. Distribution of $\sigma_{y y(R)} / \sigma_{Y S}$ along the crack front near crack tip $(x=0.007(W-a))$ 


\section{Conclusions}

Three-dimensional finite element analyses have been performed on clamped $\mathrm{SE}(\mathrm{T})$ specimens to evaluate the residual stress state introduced by the local compression method. The analysis results suggest that the distribution of the opening residual stress in the uncracked ligament is dependent on the configuration and position of the indenters. Based on the given existing residual stress state, appropriate LC technique can be used to mitigate the existing residual stress in SE(T) specimen.

\section{Acknowledgements}

This study is supported by TransCanada Corporation and the Natural Sciences and Engineering Research Council of Canada (NSERC) through the Collaborative Research and Development (CRD) program and by the NSERC-RIEM program. The authors gratefully acknowledge Dr. Henryk Pisarski, previous Technology Fellow at TWI Ltd. and Mr. James Gianetto in the Materials Technology Laboratory of Natural Resources Canada, for their discussions related to this study. Helpful comments from the anonymous reviewers are greatly appreciated.

Manuscript received by Editorial Board, October 26, 2015; final version, November 02, 2016.

\section{References}

[1] ASTM E1820-13: Standard Test Method for Measurement of Fracture Toughness, ASTM International, West Conshohocken, PA, ASTM 2013.

[2] BS 7448: Part 4. Method for Determination of Fracture Resistance Curves and Initiation Values for Stable Crack Extension in Metallic Materials. British Standards Institution, 389 Chiswick High Road, London, BSI 1997.

[3] Y. Huang, and W. Zhou. Investigation of plastic eta factors for clamped $\mathrm{SE}(\mathrm{T})$ specimens based on three-dimensional finite element analyses. Engineering Fracture Mechanics, 132:120-135, 2014.

[4] Y. Huang and W. Zhou. J-CTOD relationship for clamped SE(T) specimens based on threedimensional finite element analyses. Engineering Fracture Mechanics, 131:643-655, 2014.

[5] U. Zerbst, R.A. Ainsworth, H.T. Beier et al. Review on fracture and crack propagation in weldments-A fracture mechanics perspective. Engineering Fracture Mechanics, 132:200-276, 2014.

[6] M. Dawes. Fatigue pre-cracking weldment fracture-mechanics specimens. Metal Construction and British Welding Journal, 3:61-65, 1971.

[7] O.L. Towers and M.G. Dawes. Welding Institute research on the fatigue precracking of fracture toughness specimens. In Elastic-Plastic Fracture Test Methods. The User's Experience. ASTM STP, 856:23-46, 1985.

[8] ISO15653: Metallic materials-Method of test for the determination of quasistatic fracture toughness of welds, International Organization for Standardization, 2010. 
[9] M.R. Hill and T.L. Panontin. Effect of residual stress on brittle fracture testin. In Fatigue and Fracture Mechanics, ASTM STP 1332, 29:154-175, 1999.

[10] M.R. Hill and T. Yau. Triaxial residual stresses affect driving force and constraint to alter fracture toughness. In Proceedings of the Sixth International Conference on Residual Stresses, pages 1485-1492, Oxford, UK, 2000.

[11] A.H. Mahmoudi, C.E. Truman and D.J. Smith. Using local out-of-plane compression (LOPC) to study the effects of residual stress on apparent fracture toughness, Engineering Fracture Mechanics, 75(6):1516-1534, 2008.

[12] A.H. Mahmoudi. Influence of residual stress on fracture. Ph.D. Thesis, University of Bristol, Bristol, 2005.

[13] R.G. Hurlston, J.K. Sharples and A.H. Sherry. Understanding and accounting for the effects of residual stresses on cleavage fracture toughness measurements in the transition temperature regime. International Journal of Pressure Vessels and Piping, 128:69-83, 2015.

[14] W.-K. Lim, J.-H. Song and B.V.Sankar. Effect of ring indentation on fatigue crack growth in an aluminum plate. International Journal of Fatigue, 25(9-11):1271-1277, 2003.

[15] ABAQUS/Standard Version 6.12-2. Analysis User's manual. Dassault Systémes Simulia Corporation., Providence, RI, 2013.

[16] A. Mendelson. Plasticity: Theory and Application. Krieger Publishing Company, Malabar, Florida, 1983.

\section{Stan naprężeń szczątkowych powodowanych zastosowaniem techniki lokalnego ściskania w rozciąganej próbce $\mathrm{z}$ pojedynczym nacięciem}

Streszczenie

Trójwymiarową (3D) analizę elementów skończonych (FEA) zastosowano w celu symulacji techniki lokalnego ściskania (LC) w mocowanych na końcach rozciąganych próbkach z pojedynczym nacięciem $(\mathrm{SE}(\mathrm{T}))$. Stosowno i analizowano trzy typy wgłębników: pojedynczą parę wgłębników cylindrycznych (SPCI), podwójną parę wgłębników cylindrycznych (DPCI) i pojedynczą parę wgłębników pierścieniowych (SPRI). Dokonano oceny naprężeń szczątkowych na kierunku otworu pęknięcia w niepopękanym obszarze badanej próbki. Wyniki uzyskane w pracy mogą ułatwić stosowanie techniki lokalnego ściskania w rozciąganych próbkach z pojedynczym nacięciem. 